J. Amer. Soc. Hort. SCI. 117(2):308-312. 1992.

\title{
Allelopathic Potential of Celery Residues on Lettuce
}

\author{
Dorm G. Shilling \\ Agronomy Department, University of Florida,' Gainesville, FL 32611
}

Joan A. Dusky

Everglades Research and Education Center, P. O. Box 8003, Belle Glade, FL 33430

Mark A. Mossier

Agronomy Department, University of Florida, Gainesville, FL 32611

Thomas A. Bewick

Vegetable Crops Department, University of Florida, Gainesville, FL 32611

Additional index words. Lactuca sativa, Apium graveolens, allelopathy, activated carbon, phytotoxins, crop residues

\begin{abstract}
Poor emergence of commercially grown lettuce has been observed when planted immediately after the removal of a celery crop. Greenhouse experiments were conducted to evaluate the possible allelopathic effects of celery residue on the emergence and growth of lettuce. The influence of amount and type of celery tissue, growth medium and fertility, incubation time in soil, and amendment of growth medium containing celery residue with activated charcoal was evaluated with respect to the allelopathic potential of celery. Celery root tissue was 1.8 and 1.6 times more toxic to lettuce seedling growth than was celery petiole or lamina tissue, respectively. Lettuce shoot growth was inhibited to a greater extent when grown in sand amended with celery residue rather than either amended vermiculite or potting soil. Incubation of celery root residue in soil for 4 weeks increased phytotoxicity at $1 \%$ (v/v) and decreased it at $4 \%(\mathrm{v} / \mathrm{v})$. Increasing the fertility of pure sand with varying amounts of Hoagland's solution did not reverse the allelopathic effects of celery residue. The addition of activated carbon to the medium increased the growth of lettuce exposed to celery residues. Celery residues possess allelopathic potential to developing lettuce seedlings. Celery tissue type and concentration, soil type, incubation of celery root residue in soil, and addition of activated carbon to the growing medium influenced the magnitude of the observed phytotoxicity.
\end{abstract}

The term allelopathy has been defined by Rice (1974) as "the direct or indirect harmful effect by one plant (including microorganisms) on another through the production of chemical compounds that escape into the environment." Currently, allelopathy is understood as the inhibitory and/or stimulator effects of one plant (either microbial or higher plant) on another by the production of a chemical substance that is released into the environment (Putnam and Tang, 1986). Recent reviews on the topic are available (Duke, 1986; Putnam, 1988; Rice, 1984) and include discussion of crop residues that possess allelopathic activity under certain environmental conditions.

Many volatile constituents of celery have been isolated (MacLeod et al., 1988), including $p$ - cymene, limonene, and $\beta$ selinene, and are reported to have allelopathic activity (Fischer, 1986). Celery tissue also contains linear furocoumarins that act as phytoalexins against such pathogens as Sclerotinia sclerotiorum (LIB. ) de Barry (Beier and Oertli, 1983), Erwinia carotovora pv. carotovora (Et.) (Surico et al., 1987), and certain viruses (Lord et al., 1988). One of these compounds, psoralen, is a potent inhibitor of seed germination (Putnam, 1988). Early research indicated that psoralen reduced Lactuca germination and sprout growth at a concentration of $3.6 \times 10^{-4} \mathrm{M}$ (Brown, 1981). Psoralen isolated from Psoralea subacaulis Pursh. inhibited germination of lettuce seed at concentrations as low as 1 ppb (Baskin et al., 1967). Celery contains psoralen concentrations an order of magnitude higher than that needed to inhibit lettuce germination (Beier et al., 1983). Psoralen was identified as a major linear furocoumarin constituent of copper sulfate-

Received for publication 9 May 1991. Accepted for publication 28 Oct. 1991. Florida Agr. Expt. Sta. Bul. no. R-01579. The cost of publishing this paper was defrayed in part by the payment of page charges. Under postal regulations, this paper therefore must be hereby marked advertisement solely to indicate this fact. treated celery, suggesting that psoralen production can be stimulated by $\mathrm{Cu}^{+2}$ in the absence of pathogenic organisms (Beier and Oertli, 1983). Compounds containing copper are recommended to control a number of bacterial and fungal diseases of celery (Sherf and MacNab, 1986).

Over a period of several years, vegetable growers in the Everglades Agricultural Area of Florida have reported that lettuce, planted soon after the harvest of celery, emerged poorly and more slowly than normally expected (D. Botts, personal communication). The resulting lettuce stand, combined with a nonuniform harvest period, was commercially unacceptable. Other crop residues, including barley (Hordeum vulgare L.) and rye (Secale ceveale L.), reduced emergence and growth of lettuce in California (Patrick et al., 1963). The purpose of our studies was to determine whether celery residue incorporated into soil reduces the emergence and growth of lettuce under controlled greenhouse conditions and, if so, to study several variables that might influence this effect.

\section{Materials and Methods}

Growth media and type and amount of celery tissue. Treatment variables were arranged factorially $(3 \times 3 \times 6)$ to evaluate any interactive effects. Three growth media were used (all per $425-\mathrm{cm}^{3}$ pot): 1) $110 \mathrm{~g}$ of a high organic matter potting medium that contained $30 \%$ sphagnum peat, $50 \%$ vermiculite, $18 \%$ perlite, and $2 \%$ sand (by volume) (Metro-mix, Gracewood Horticultural Products, Cambridge, Mass.); 2) $200 \mathrm{~g}$ of $100 \%$ vermiculite; and 3) $610 \mathrm{~g}$ of $100 \%$ quartz sand. The media were not sterilized before use. Celery, grown using standard commercial practices and obtained from the Everglades Agricultural Area, Belle Glade, Fla., was harvested at a time corresponding to commercial harvest, air-dried, and stored at 0C until use. Celery tissues evaluated for allelopathic potential were divided 
into petioles, laminas, and roots. Celery residue was incorporated into the media at $0,1.1,2.2,4.4,8.8$, or $13.2 \mathrm{~g} / 425-\mathrm{cm}^{3}$ pot, which corresponded to $0,0.5 \%, 1 \%, 2 \%, 4 \%$, and $6 \%$ (v/v). Because the media had vastly different densities, residue percentages were established on a volume basis so that the percentage of residues per gram of medium would be the same.

Celery residues were incorporated into the soils by vigorously shaking the components in paper bags. Immediately after incorporation, pots were filled and 30 'Iceberg' lettuce (commercial crisphead lettuce type) seeds per pot were planted $0.5 \mathrm{~cm}$ deep. The soil mixture was then saturated with water by subirrigation. Preliminary studies were conducted to determine lettuce growth in the three soil types in response to fertility (data not shown). Ten milliliters of a $2 \times$ Hoagland solution (Hoagland and Arnon, 1950) was applied one, two, or three times per week to lettuce growing in potting soil, vermiculite, or sand, respectively. These levels of fertility input for each growth medium were shown to optimize lettuce growth (data not shown).

Incubation of celery residue in soil. Treatments included three celery root residue percentages $[0 \%, 1 \%$, and $4 \%(\mathrm{v} / \mathrm{v}) ; 0,2.2$, and $8.8 \mathrm{~g} / \mathrm{pot}$, respectively] and four incubation periods $(0,4$, 8 , and 12 weeks) arranged factorially. Celery root residue was thoroughly mixed with $370 \mathrm{~g}$ of an Arredondo fine sand soil (loamy, siliceous, hyperthermic Grossarenic Paleudult) as described previously. The soil was kept moist throughout the experiment by subirrigation. The 0 incubation period was established by planting 30 'Iceberg' seeds $0.5 \mathrm{~cm}$ deep immediately after mixing the celery residue and soil and filling $425-\mathrm{cm}^{3}$ pots with this mixture. Four, eight, and 12 weeks after the soil/residue mixture had been added to the pots (i.e., the different incubation periods), one-fourth of the experiment was seeded to lettuce as described previously. All treatments were fertilized with $20 \mathrm{ml}$ of $1 \times$ Hoagland solution at the time of planting. Lettuce emergence data were recorded at 7, 14, and 28 days after sowing, and lettuce shoots were harvested at 28 days after sowing.

Fertility study. Treatments were 0, 20, 40, 50, 100,200, and $400 \mathrm{ml}$ of $1 \times$ Hoagland solution applied per week both with and without $2.25 \%(\mathrm{v} / \mathrm{v})$ celery root residue. Lettuce was seeded $0.5 \mathrm{~cm}$ deep (30 seeds per $425-\mathrm{cm}^{3}$ pot) in pure quartz sand that was saturated with water by subirrigation. Subsequent irrigation was accomplished with a combination of nutrient solution and subirrigation.

Activated carbon study. Treatments included three percentages of activated carbon $[0 \%, 6 \%$, and $12 \%(\mathrm{v} / \mathrm{v}) ; 0,6$, and 12 $\mathrm{g} /$ pot, respectively] and four percentages of celery root residue $[0 \%, 0.5 \%, 1.0 \%$, and $2.0 \%(\mathrm{v} / \mathrm{v})]$ arranged factorially. After the appropriate amounts of celery residue and activated carbon were homogenized with sand, $425-\mathrm{cm}^{3}$ pots were filled with the mixtures. Lettuce was seeded $0.5 \mathrm{~cm}$ deep (30 seeds per pot) and the pots saturated with water by subirrigation. Lettuce was fertilized twice a week with $10 \mathrm{ml}$ of $5 \mathrm{x}$ Hoagland's solution.

Plant maintenance, harvest, and statistical design and analysis. Lettuce was maintained in a glass greenhouse $(30 \pm 5 \mathrm{C})$. Routine watering was accomplished by subirrigation. Nutrient solution was applied as a drench when used. Lettuce emergence was determined 7, 14, and 28 days after the initiation of all experiments. After 28 days of growth, lettuce was harvested, shoot and root tissues were separated, dried at 90C for 3 days, and weighed. Accurate root weights could not be determined in either potting medium or vermiculite because the media particles adhered tightly to lettuce roots. No supplemental lighting was used.

All treatments were replicated three times and each study conducted twice using a randomized complete-block design. Data. were initially analyzed using analysis of variance to test for treatment effects and interactions. Because there were no experiment $\mathrm{x}$ treatment interactions $(P>0.05)$, data were combined across experiments. Regression analysis was used to determine the concentration of celery residue required to cause $50 \%$ inhibition of lettuce growth ( $I_{50}$ value); $95 \%$ confidence intervals were calculated for each $I_{50}$ value (Draper and Smith, 1981). Specific information dealing with the mean separation procedures is presented with the data.

\section{Results and Discussion}

Growth media and type and amount of celery tissue. Growth medium influenced the degree of response of lettuce to celery residues (Table 1 ). As the $I_{50}$ value decreased, the phytotoxicity of the residue increased because less residue was required to cause the same amount of growth inhibition. In terms of shoot biomass, celery residue was more phytotoxic in sand than either vermiculite or potting medium, possibly because of the greater availability of putative allelopathic compounds due to reduced adsorption by the inert sand. When lettuce was grown in vermiculite or potting medium it was initially less susceptible (larger $\mathrm{I}_{50}$ values) to celery residue as indicated by emergence data. There are several possible explanations for the transient effect of celery residue in these media on lettuce emergence. First, over the 28-day study period, the toxicity of the residue could have increased due to activation and/or release of phytotoxic compound(s). Second, some of the lettuce seedlings that initially emerged died either due to damping-off or due to some

Table 1. Effect of soil type on phytotoxic effect of celery residue on lettuce growth. Inhibition values given are the means of two experiments.

\begin{tabular}{|c|c|c|c|c|c|}
\hline \multirow[b]{2}{*}{ Soil type } & \multicolumn{3}{|c|}{ Emergence (days) } & \multirow{2}{*}{$\begin{array}{c}\text { Shoot } \\
\text { biomass } \\
(\mathrm{g})\end{array}$} & \multirow{2}{*}{$\begin{array}{c}\text { Root } \\
\text { biomass } \\
\text { (g) }\end{array}$} \\
\hline & 7 & 14 & 28 & & \\
\hline \multicolumn{6}{|c|}{$I_{50}$ values $^{\mathrm{z}}$} \\
\hline Sand & $\begin{array}{c}2.7 \\
(2.58-2.82)\end{array}$ & $\begin{array}{c}2.4 \\
(2.31-2.49)\end{array}$ & $\begin{array}{c}2.5 \\
(2.36-2.64)\end{array}$ & $\begin{array}{c}1.7 \\
(1.49-1.91)\end{array}$ & $\begin{array}{c}2.0 \\
(1.83-2.17)\end{array}$ \\
\hline Vermiculite & $\begin{array}{c}2.8 \\
(2.60-3.00)\end{array}$ & $\begin{array}{c}2.3 \\
(2.16-2.46)\end{array}$ & $\begin{array}{c}2.2 \\
(2.09-2.31)\end{array}$ & $\begin{array}{c}2.2 \\
(2.05-2.35)\end{array}$ & --- \\
\hline Potting soil & $\begin{array}{c}3.0 \\
(2.91-3.09)\end{array}$ & $\begin{array}{c}2.8 \\
(2.64-2.96)\end{array}$ & $\begin{array}{c}2.5 \\
(2.41-2.59)\end{array}$ & $\begin{array}{c}2.3 \\
(2.21-2.39)\end{array}$ & -- \\
\hline
\end{tabular}

${ }^{2}$ Percentage of celery residue, on a volume-to-volume percentage basis, required to cause $50 \%$ inhibition with $95 \%$ confidence intervals underlying each $\mathrm{I}_{50}$ value in parentheses. All $I_{s 0}$ values were derived from statistically significant linear regression equations with $R^{2}$ values of 0.87 or higher. 
Table 2. Effect of tissue type on phytotoxic effect of celery residue on lettuce growth. Inhibition values given are the means of two experiments.

\begin{tabular}{lccccc}
\hline \hline $\begin{array}{l}\text { Celery } \\
\text { tissue } \\
\text { type }\end{array}$ & \multicolumn{3}{c}{\begin{tabular}{c} 
Emergence (days) \\
\cline { 2 - 4 }
\end{tabular}} & 7 & \multicolumn{2}{c}{14} & $\begin{array}{c}\text { Shoot } \\
\text { biomass } \\
(\mathrm{g})\end{array}$ & $\begin{array}{c}\text { Root } \\
\text { biomass } \\
(\mathrm{g})\end{array}$ \\
\hline Root & 2.0 & 1.9 & 1.8 & 1.6 & 1.3 \\
& $(1.87-2.13)$ & $(1.77-2.03)$ & $(1.74-1.86)$ & $(1.51-1.69)$ & $(1.14-1.45)$ \\
Lamina & 2.5 & 2.7 & 2.7 & 2.5 & 1.7 \\
& $(2.34-2.66)$ & $(2.56-2.84)$ & $(2.54-2.86)$ & $(2.36-2.64)$ & $(1.42-1.96)$ \\
Petiole & 2.7 & 2.7 & 2.8 & 2.8 & 2.3 \\
& $(2.56-2.84)$ & $(2.58-2.82)$ & $(2.72-2.89)$ & $(2.68-2.92)$ & $(2.19-2.41)$ \\
\hline
\end{tabular}

${ }^{2}$ Percentage of celery residue, on a volume-to-volume percentage basis, required to cause $50 \%$ inhibition with $95 \%$ confidence intervals underlying each $\mathrm{I}_{50}$ value in parentheses. All $\mathbf{I}_{50}$ values were derived from statistically significant linear regression equations with $R_{2}$ values of 0.87 or higher.

Table 3. Interaction of celery root residue and incubation period on growth of lettuce. Numbers are the means of two experiments. ${ }^{2}$

\begin{tabular}{|c|c|c|c|c|c|c|}
\hline \multirow{2}{*}{$\begin{array}{l}\text { Celery root } \\
\text { residue percentage } \\
(\mathrm{v} / \mathrm{v})\end{array}$} & \multirow{2}{*}{$\begin{array}{l}\text { Incubation } \\
\text { period } \\
\text { (weeks) }\end{array}$} & \multicolumn{3}{|c|}{ Emergence (days) } & \multirow{2}{*}{$\begin{array}{l}\text { Shoot } \\
\text { biomass } \\
(\mathrm{g})\end{array}$} & \multirow{2}{*}{$\begin{array}{c}\text { Root } \\
\text { biomass } \\
\text { (g) }\end{array}$} \\
\hline & & 7 & 14 & 28 & & \\
\hline \multirow[t]{4}{*}{1} & 0 & $0 \mathrm{a}$ & $0 \mathrm{a}$ & $1 \mathrm{a}$ & $0 \mathrm{a}$ & $0 \mathrm{a}$ \\
\hline & 4 & $19 \mathrm{~b}$ & $29 \mathrm{~b}$ & $27 \mathrm{~b}$ & $38 \mathrm{~b}$ & $31 \mathrm{~b}$ \\
\hline & 8 & $0 \mathrm{a}$ & $0 \mathrm{a}$ & $0 \mathrm{a}$ & $0 \mathrm{a}$ & $0 \mathrm{a}$ \\
\hline & 12 & $0 \mathrm{a}$ & $2 a$ & $0 \mathrm{a}$ & $0 \mathrm{a}$ & $0 \mathrm{a}$ \\
\hline \multirow[t]{4}{*}{4} & 0 & $80 \mathrm{~d}$ & $64 \mathrm{c}$ & $60 \mathrm{c}$ & $56 \mathrm{c}$ & $74 \mathrm{c}$ \\
\hline & 4 & $68 \mathrm{c}$ & $35 \mathrm{~b}$ & $30 \mathrm{~b}$ & $35 \mathrm{~b}$ & $53 \mathrm{~b}$ \\
\hline & 8 & $47 \mathrm{~b}$ & $32 \mathrm{~b}$ & $26 \mathrm{~b}$ & $0 \mathrm{a}$ & $53 \mathrm{~b}$ \\
\hline & 12 & $34 \mathrm{a}$ & $21 \mathrm{a}$ & $0 \mathrm{a}$ & $0 \mathrm{a}$ & $1 \mathrm{a}$ \\
\hline
\end{tabular}

"Mean separation within columns within a celery residue percentage at $P=0.05$ as determined by single degree-of-freedom orthogonal comparisons.

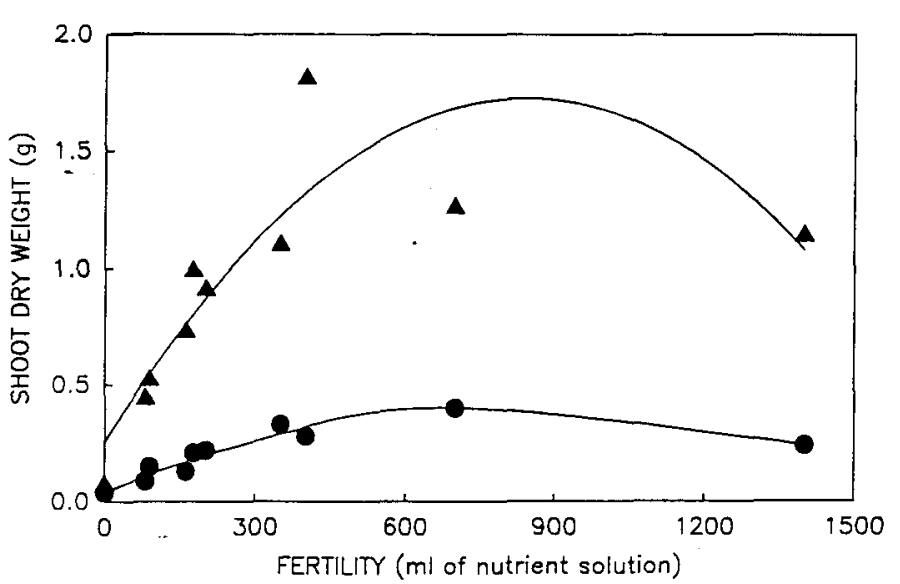

Fig. 1. Effect of fertility and celery root residue on lettuce shoot growth. The quadratic curves are significant at $P<0.05$. (A) No residue $\left(\mathrm{y}=-0.000002 \mathrm{x}^{2}+0.004 \mathrm{x}+0.26, R^{2}=0.76\right) ;(\bullet)$ with residue $\left(\mathrm{y}=0.0000005 \mathrm{x}^{2}+0.0009 \mathrm{x}+0.05, R^{2}=0.93\right)$.

direct effect from the celery residue that resulted in eventual death (e.g., reduced root growth that would not effect initial emergence but would influence long-term viability) (Patrick et al., 1964). Third, the compound(s) active in celery tissue may affect seedling growth more than emergence.

Overall, celery root tissue was more toxic to lettuce growth than celery petiole and lamina tissue (Table 2). Based on lettuce shoot weight, celery root tissue was 1.8 and 1.6 times more toxic than celery petiole and lamina tissue, respectively. Based on lettuce root weight, celery root tissue was 1.8 and 1.3 times

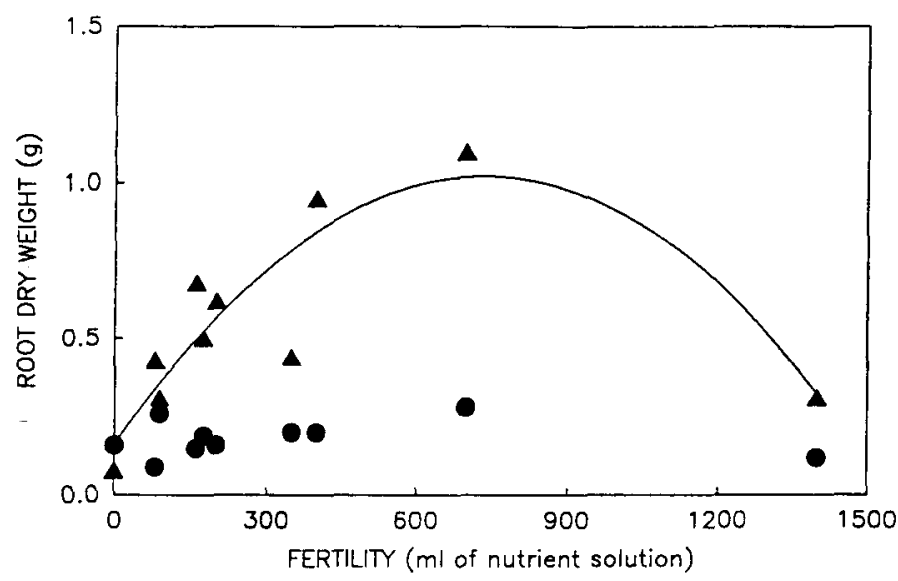

Fig. 2. Effect of fertility and celery root residue on lettuce root growth. The quadratic curve for no residue is significant at $P=0.05$. (A) No residue $\left(\mathrm{y}=-0.000001 \mathrm{x}^{2}+0.002 \mathrm{x}+0.16, R^{2}=0.78\right)$. Fertility did not significantly influence lettuce growth when celery root residue was present $(P>0.05)$. (•) With residue.

more toxic than celery petiole and lamina tissue, respectively. Celery root tissue was also more inhibitory to lettuce emergence than either lamina or petiole tissue. Differences in phytotoxicity of various tissues have been reported previously (Guenzi et al., 1967; May and Ash, 1990; Putnam and Tang, 1986; Rice, 1974). Such differences might be related to allelopathic compounds being produced in larger quantities in certain tissues, imparting a higher level of toxicity. Release of phytotoxic compounds 
Table 4. Interaction of celery root residue and activated carbon percentage on growth of lettuce. Numbers are the means of two experiments. ${ }^{2}$

\begin{tabular}{|c|c|c|c|c|c|c|}
\hline \multirow{2}{*}{$\begin{array}{l}\text { Celery root } \\
\text { residue percentage } \\
\text { (v/v) }\end{array}$} & \multirow{2}{*}{$\begin{array}{l}\text { Activated } \\
\text { carbon } \\
\text { percentage } \\
(v / v)\end{array}$} & \multicolumn{3}{|c|}{ Emergence (days) } & \multirow{2}{*}{$\begin{array}{c}\text { Shoot } \\
\text { biomass } \\
\text { (g) }\end{array}$} & \multirow{2}{*}{$\begin{array}{c}\text { Root } \\
\text { biomass } \\
\text { (g) }\end{array}$} \\
\hline & & 7 & 14 & 28 & & \\
\hline \multicolumn{7}{|c|}{ Inhibition (\%) } \\
\hline \multirow[t]{3}{*}{0.5} & 0 & $12 \mathrm{~b}$ & $43 \mathrm{~b}$ & $59 \mathrm{~b}$ & $61 \mathrm{~b}$ & $69 \mathrm{c}$ \\
\hline & 6 & $16 \mathrm{~b}$ & $40 \mathrm{~b}$ & $46 \mathrm{~b}$ & $53 \mathrm{~b}$ & $33 \mathrm{~b}$ \\
\hline & 12 & $0 \mathrm{a}$ & $12 \mathrm{a}$ & $11 \mathrm{a}$ & $10 \mathrm{a}$ & $15 \mathrm{a}$ \\
\hline \multirow[t]{3}{*}{1.0} & 0 & $30 a$ & $55 \mathrm{~b}$ & $58 \mathrm{~b}$ & $74 \mathrm{~b}$ & $71 \mathrm{~b}$ \\
\hline & 6 & 39 a & $36 \mathrm{a}$ & $35 \mathrm{a}$ & $65 \mathrm{~b}$ & 58 a \\
\hline & 12 & $35 \mathrm{a}$ & $34 \mathrm{a}$ & $20 \mathrm{a}$ & $40 \mathrm{a}$ & $45 \mathrm{a}$ \\
\hline \multirow[t]{3}{*}{2.0} & 0 & $40 \mathrm{a}$ & $38 \mathrm{a}$ & $43 \mathrm{~b}$ & $74 \mathrm{~b}$ & $70 \mathrm{~b}$ \\
\hline & 6 & $44 \mathrm{a}$ & $52 \mathrm{~b}$ & $45 \mathrm{~b}$ & $60 \mathrm{a}$ & $40 \mathrm{a}$ \\
\hline & 12 & $41 \mathrm{a}$ & $30 \mathrm{a}$ & $27 \mathrm{a}$ & $54 \mathrm{a}$ & $35 \mathrm{a}$ \\
\hline
\end{tabular}

${ }^{2}$ Mean separation within columns within a celery root residue percentage at $P=0.05$ as determined by single degree-of-freedom orthogonal comparisons.

could also be affected by tissue type. Leaf and petiole tissues are covered with cuticle and are more lignified than root tissue. Both of these factors could potentially regulate the release of allelopathic compounds.

Incubation of celery residue in soil. Incubation enhanced the toxicity of celery residue at $1 \%(\mathrm{v} / \mathrm{v})$ only after 4 weeks, but progressively reduced it at $4 \%(\mathrm{v} / \mathrm{v})$ (Table 3$)$. At the lower percentage, partial tissue degradation may have been necessary to release a sufficient amount of the compound(s) responsible for inhibition of lettuce growth. At the higher percentage, the critical amount of allelopathic compound(s) could have been released more rapidly. There was no inhibition of lettuce growth at the 8- and 12-week incubation periods for $1 \%(\mathrm{v} / \mathrm{v})$, probably because the toxic compounds had undergone degradation. Both activation (i.e., incubation enhancing phytotoxicity) and degradation (i.e., incubation reducing phytotoxicity) have been reported previously (Guenzi et al., 1967; May and Ash, 1990; Nair et al., 1990; Patrick, 1971).

These data support the contention that celery residue contains and potentially releases organic compound(s) that exert an allelopathic effect toward lettuce. One percent $(\mathrm{v} / \mathrm{v})$ of celery root residue would be equivalent to $0.5 \%$ on a weight-to-weight basis for the soil used in this experiment. This degree of toxicity generally was as, or more, toxic than that of plant residues that have been reported (Putnam and Tang, 1986; Rice, 1974).

Fertility effect. To further substantiate that the potential allelopathic effect of celery residue on lettuce growth was not due to changes in $\mathrm{C}: \mathrm{N}$ ratio [which would alter nutrient concentrations through microbial assimilation (Alexander, 1977)], fertility studies were conducted. Celery root residue reduced lettuce shoot growth by $70 \%$ when grown at the maximum fertility level used in these experiments (Fig. 1). In the presence of celery residue, there was only a slight increase in lettuce shoot growth with increasing fertility. Fertility did not significantly affect the response of lettuce root growth to celery root residue (Fig. 2). The lettuce growth response was probably not due to an altered $\mathrm{C}: \mathrm{N}$ ratio caused by celery residue but instead due to the allelopathic nature of celery residue.

Activated carbon effect. This study was conducted to determine whether the addition of activated carbon, which is known to bind and inactivate many organic compounds, would reduce or eliminate the allelopathic effect of celery residue on lettuce growth; however, absorptivity varies with the chemical nature of the compound (Mattson and Mark, 1971).
Carbon alone had no effect on the growth of lettuce (data not shown). However, the allelopathic effect of celery residue on lettuce growth was reduced as carbon concentration increased (Table 4). Activated carbon partially reversed the inhibitory effect of celery residue on lettuce growth, presumably by adsorbing phytotoxic compounds produced by celery, but total reversal was absent, probably because the charcoal did not adsorb 100\% of the toxic substances.

Various factors were shown to influence the magnitude of lettuce growth inhibition by celery residue, including 1) tissue type and amount, 2) growth medium used, 3) incubation of the residue soil mixture, and 4) the presence of activated carbon. Collectively, these data support the hypothesis that celery residue has allelopathic potential. The alteration of $\mathrm{C}: \mathrm{N}$ ratio in soils, leading to rapid assimilation of $\mathrm{N}$ by microorganisms, is known to reduce early plant growth (Alexander, 1977). If celery residue inhibited lettuce growth by altering $\mathrm{C}: \mathrm{N}$ ratio, then adding a small amount of residue to a highly organic medium should have had no effect. Incubation also would not have enhanced inhibition, and increased fertility would have overcome inhibition. Lastly, if celery residue had inhibited lettuce growth indirectly by altering $\mathrm{C}: \mathrm{N}$ ratio, the addition of activated carbon would have had no effect.

It is often difficult to conclude from greenhouse experiments whether an allelopathic effect has actually occurred. Ultimately, isolation, characterization, and proof that certain compounds are the cause of the inhibitory effect is necessary to unequivocally prove allelopathy (Putnam and Tang, 1986).

\section{Literature Cited}

Alexander, M. 1977. Introduction to soil microbiology. 2nd ed. Wiley, New York. p. 467.

Baskin, J.M., C.J. Ludlow, T.M. Harris, and F.T. Wolfe. 1967. Psoralen, an inhibitor in the seeds Psoralea subacaulis (Leguminosea). Photochemistry 6:1209.

Beier, R. C., G.W. Ivie, E.H. Oertli, and D.L. Holt. 1983. HPLC analysis of linear furocoumarins (psoralens) in healthy celery (Apium graveolens). Food Chem. Toxicology 21:163-165.

Beier, R.C. and E.H. Oertli. 1983. Psoralen and other linear furocoumarins as phytoalexins in celery. Photochemistry 22:2595-2597.

Brown, S.A. 1981. Coumarins, p. 286-287. In: P.K. Stumpf and E.E. Corm (eds.). The biochemistry of plants: A comprehensive treatise vol. 7. Secondary plant products. Academic, New York.

Draper, N.R. and H. Smith. 1981. Applied regression analysis. 2nd ed. Wiley, New York. p. 47-49. 
Duke, S.0. 1986. Naturally occurring chemical compounds as herbicides. Rev. Weed Sci. 2:17-65.

Fischer, N.H. 1986. The function of mono and sesquiterpenes as plant germination and growth regulators, p. 203-218. In: A.R. Putnam and C. Tang (eds. ). The Science of allelopathy. Wiley, New York.

Guenzi, W. D., T.M. McCalla, and F.A. Norstadt. 1967. Presence, and persistence of phytotoxic substances in wheat, oat, corn, and sorghum residues. Agron. J. 59:163-165.

Hoagland, D.R. and D.I Amen. 1950. The water-culture method for growing plants without soil. Calif. Agr. Expt. Sta., Berkeley. Circ. 347.

Lord, K. M., H.A.S. Epton, and R.R. Frost. 1988. Virus infection and furocoumarins in celery. Plant Pathology 37:385-389.

MacLeod, A.J., G. MacLeod, and G. Subramanian. 1988. Volatile aroma constituents of celery. Photochemistry 27:373-375.

Mattson, J.S. and H.B. Mark. 1971. Activated carbon. Marcel Dekker, New York.

May, F.E. and J.E. Ash. 1990. An assessment of the allelopathic potential of Eucalyptus. Austral. J. Bet. 38:245-254.

Nair, M. G., C.J. Whitenack, and A.R. Putnam. 1990. 2,2'-OXO-1,1', azobenzene a microbially transformed allelochemical from 2,3-benzoxazolinone: I. J. Chem. Ec oL 16:353-364.

Patrick, Z.A. 1971. Phytotoxic substances associated with the decomposition in soil of plant residues. Soil Sci. 111:13-18.

Patrick, Z. A., T.A. Toussoun, and L.W. Koch. 1964. Effect of cropresidue decomposition products on plant roots. Annu. Rev. Phytopathology 2:627-292.

Patrick, Z. A., T.A. Toussoun, and W.C. Snyder. 1963. Phytotoxic substances in arable soils associated with decomposition of plant residues, Phytopathology 53: 152-161.

Putnam, A.R. 1988. Allelochemicals from plants as herbicides. Weed Technol. 2:510-518.

Putnam, A.R. and C. Tang. 1986. The science of allelopathy. Wiley, New York.

Rice, E.L. 1974. Allelopathy. Academic, New York.

Rice, E.L. 1984. Allelopathy. 2nd ed. Academic, Orlando, Fla.

Sherf, A.F. and A.A. MacNab. 1986. Vegetable diseases and their control. p. 157-201. Wiley, New York.

Surico, G., L. Varvaro, and M. Solfrizzo. 1987. Linear furocoumarin accumulation in celery plants infected with Erwinia carotovora pv. carotovora. J. Agr. Food Chem. 35:406409. 